\title{
The students' aggressiveness in senior high school based on gender
}

\author{
Anna Ayu Herawati ${ }^{1}$, Herman Nirwana ${ }^{2}$, Syahniar ${ }^{3}$ \\ ${ }^{123}$ Universitas Negeri Padang, Padang - Indonesia, (liza.halimatulhumairah@yahoo.com)
}

\begin{abstract}
Student has a different level of aggressiveness, this was influenced by various factors one of them is gender. Aims of this research is to examine differences the aggressiveness students based on gender. The method was ex post facto with a 2 groups design. Thepopulation is 566 and samples were 234 students. Sampling technique used stratified random sampling.The instrument usedAggressiveness Scale, with reliability scoreis 0,936. Data were analyzed by using the descriptive statistics and anova. The results of this research show that there is a significant difference of aggressiveness in terms of gender. The implication of this research can be used as students need assessment to make improvement a program of guidance and counseling.
\end{abstract}

Keywords: aggressiveness, gender, student Padang.

\section{Introduction}

Education has an important role in developing students' potential. Through education, students are taught a variety of good things. Students are expected to be able to control themselves in accordance with devotion to God Almighty, intelligent accordance with all its potential, has skills in accordance with the values and norms, as well as having a good personality. A student is the younger generation successor to the nation who are studying in educational institutions. Educational institutions in which there is the role of guidance and counseling, which aims to pay attention to the existence, functions, and volume of the service which is the embodiment of professionalism towards guidance and counseling (BK) in educational institutions. The term "counseling for all" that leads to all the target service with a wide range of variables such as: age, sex, family, marriage, education, employment, and socioeconomic conditions with various problems of human life (Supriatna \& Budiman 2009; Prayitno 2012; Mufrihah 2014 ).

Through the implementation of guidance and counseling services (BK) in the school, students are expected not only focused on the mastery of the subject matter alone but should be able to develop all their potential, able to control themselves, have the expertise to solve the problems. Emotions on students have an important role for the problem or conflict. Emotional expression of a person is a common thing when done properly (Shaffer, 2005; Shahada, 2013; Paiesa, 2017). An improper emotional expression may lead to conflict, and gives rise to the symptoms of aggressiveness 
students. This is contrary to the educational goals that form the intelligent character on the nation's future. Through the medium of television, article, or other news media still often seen violence in schools. Violence or aggressiveness among students has been a concern and a special spotlight for teacher guidance and counseling (BK) to immediately address the issue of student behavior.

The role of guidance and counseling services (BK) in schools is essential to uncover and identify the causes of aggression among students, helping students to inculcate an attitude of tolerance with all the differences that exist such as gender differences, differences in culture, religion, socioeconomic status, and so forth in order do not lead to conflict and trigger aggressiveness of the students. Aggressiveness school students in the form of student misbehavior that led to violence, hurt others intentionally kicked a chair at school, mocked, saying rude insults, contempt, and repression. Aggressiveness is an individual behavior has a purpose to injure others by shape physically, verbally and in property damage (Atkinson, Atkinson \& Hilgard, 1983; Kartono, 2005; Fadila, 2013; Novita, 2017). Aggressiveness is seen as a form of response which delivers stimulus violence to other living beings (Krahe, 2005; Herath, Dharmayana, \& Sholihah, 2014). The intent of the statement, which describes the aggressiveness of a response or behavior to harm other individuals.

The study found that the level of aggressiveness of students is quite high (Aziz \& Mangestuti 2006; Diana \& Retnowati, 2009; Pratt, Masum, \& Khan, 2014; Winarlin, Lasan, and Widada,2016).Syahniar \& Karneli (2016) showed aggressive behavior in students that occurred in the city of Padang secondary schools in middle category with a percentage of $46 \%$. The occurrence of aggressiveness must not be separated from some of the factors that affect the tendency of the aggressiveness of the students, among which self-identity, self-control, age, gender, and socioeconomic environment (Santrock, 2003; Kartono, 2005). Krahe (2005) factors that affect the onset of aggressiveness, namely: (1) biological and psychological factors, reviewed the biological aggressiveness of inherited through the genes of parents, while psychologically aggressive seen as a human instinct, their frustration, the expression of various emotional related to the level of a person's emotional intelligence to manage the emotions and how to express his emotions; (2) The individual differences in aggressiveness factors include poor social conditions such as poverty, gender differences, the influence of the media and the relationship of parent and child; (3) situational factors such as the effects of alcohol, environmental conditions such as space limitations and the high temperatures; and (4) factors short-term and long-term effect of increasing aggressiveness in the form of violence in the media.

Some things that affect the aggressiveness of a person is one of them because of factors out of ourselves, individual differences such as socioeconomic status, living environment that is hot, social pressure, sex, peer influence, an influence of the media, and family relations. The level of aggressiveness of a person's tendency can be seen from the difference between the sexes. Males have a high level of physical aggressiveness. Aggressiveness is found more often in high school and boys tend to commit violence than female students. The existence of a person's sex differences in aggressiveness associated with higher testosterone levels in males (Krahe, 2005; Aulya, Ilyas \& Ifdil, 2016).

Little research results, Henrich, Jones \& Hawley (2003) showed that the difference in aggressiveness between the sexes, ethnic and age differences varied. Furthermore, these studies 
indicate that the trend of male aggressiveness higher. Although many studies claim that boys tend to be more aggressive than women, does not mean that the aggressiveness of the girls did not exist. According Björkqvist \& Niemela (in Krahe, 2005) found that the percentage of women having verbal aggressiveness tendencies such as spreading rumors and saying rude words.

Divine research results, Syahniar and Ibrahim (2013) explains that all forms of student behavior such as breaking school discipline and especially do aggressiveness are influenced by environmental factors surrounding communities a place to stay. Ramirez (2015) found that the comparison of the level of aggressiveness of the six countries showed similar, and aggressiveness is influenced by some cultural differences in it. Sawalkar (2015) found that differences in the aggressiveness of the students who live in the village and in the city. This suggests that a person's behavior is influenced by neighborhood. Forms of aggressiveness other students who obtained based on information from counseling teacher at SMAN Lebong Sakti on March 21, 2017 states that there are some students who are involved in fighting amongst peers and involved beatings carried out by a male student with a temporary teacher young, it was triggered because dislike of young students towards teachers.

Based on these descriptions, there is a difference of opinion about the factors that influence the aggressiveness of students, ie difference between the sexes. The purpose of research is to examine differences in the aggressiveness of the students in terms of gender.

\section{Method}

This research type is descriptive comparative. The study population is students' cultural backgrounds and Serawai Rejang many as 566 students with a sample of 234 students. Mechanical sampling using stratified random sampling. Instruments such as scale. Likert aggressiveness scale Aggressiveness scale reliability test results of students using the formula Cronbach Alpha of 0.936. In addition, also used the technique halved to halve the items based on the value of 0.947 . To determine differences in the aggressiveness of the students in terms of gender, were analyzed using analysis of variance (ANOVA).

\section{Results and Discussion}

\section{The Different of Student's Aggressiveness Based on Gender}

A study shows that there is a significant pebedaan aggressiveness of the students in terms of gender, which means that the students manifold calamine men and women have different aggressiveness. This is indicated by the value of F obtained amounted to 37.968 with Sig. $\leq 0.0000 .05$ which means there are significant differences between the aggressiveness of middle school students in terms of gender and male aggressiveness resulted in a score higher than women.

The findings research indicate that the aggressiveness of middle school students in terms of male gender is in category (S) and daughters that are in the category (S). This means that the level of aggressiveness of students remained at the alarming level, but should act aggressiveness student needs to keep suppressed so it does not happen again their aggressiveness among students.

The findings also showed that there are significant differences from the aggressiveness of the students in terms of gender, meaning that boys and girls have different levels of aggressiveness. Perbedaan the aggressiveness of boys and girls is a reasonable thing to happen, this could be caused 
by the biological and psychological and environmental influences teach men accustomed to be rational and to vent negative emotions through physical feelings. Since childhood, boys more opportunity to get a toy pistol, a sword and a toy that are tools of violence. This makes the behavior patterns of boys in its development became accustomed role as a strong child, the child is able to perform the objects of violence such as kicking, boxing and even fight.

Unlike the girls are accustomed from childhood have skills better verbal than physical ability. Due to the habit of the values that have formed since the first then make girls tend to feel anxiety, guilt, fear of not even being able to do things that are violent or aggressive actions. Furthermore, the influence of electronic media or social influence, reveals that men seem more powerful than women, many television broadcasts are often circulated that the boy had a considerable role in the field of violence, while women are responsible for feminine and have the verbal skills higher compared to men, for example, was famous women with chatty or talkative and emotional engagement in the act, while men act according to the logic, more active with physical activity and easy violent or more aggressive.

This is supported by research that girls tend to be less aggressive than boys, girls tend to be less open to show their aggression physically (Maharani \& Andayani,2003; Darmayanti, 2008).Furthermore, Berry, Poortinga, Segal, \& Dasen (2002) explains that the ideology of the role of gender is a normative belief about what and how should men and women, what should be done each and so on.

Beliefs that exist in society about what women and men as to what will certainly affect behavior in boys and girls. Boundless (in Budiarti, 2015)"SexRefers to the physical or physiological differences between male, female, and intersex bodies, Including both primary sex characteristics(Reviews those related to the reproductive system) and secondary sex characteristics ". It can be interpreted that the sex differences in men and women both physically and physiologically characterized by differences in primary or secondary characteristics. Furthermore, area, Nirvana \& Bentri (2016) when viewed from the social and communication styles between boys and girls is different it is clear, in speaking women often seem less assertive than men.

Koeswara (1988) the aggressiveness researchers believe that their sexual differences in aggressiveness, men are more aggressive than women. In line with the previous opinion, that man is considered stronger than women, and women tend to show real emotion, so that makes them look weak (Aldrich \& Tenenbaum, 2006; Mahmudah, 2012). Furthermore, Garaigordobil, Maganto, Perez \& Sansinenea (2009) also explains that"Boys tend range to display more aggressive, antisocial, delinquent or externalizing behaviors, whereas girls present more anxious-depressive or internalizing problems". This means that about how men are expected to be stronger than women. Strong in question are boys tend to be more aggressive, antisocial behavior external direction, while girls had more anxiety, depressive, and internalizing problems so that said weaker than men.

Guidance services Counseling (BK) was applied to help improve the ability of learners arrange themselves in dealing with various issues and various individual differences. The individual differences can lead to conflict and generate aggressiveness of students, such as the difference between the sexes and how to manage emotions, social status differences, differences in cultural background of students who make the student's behavior varies according to the habits of the students. This confirms that the public perception of early marriage is influenced by education level and background. culturalFurthermore, in the implementation of counseling services, is expected to 
consider would be differences in the level of education and cultural background in determining the priority target of the service.

\section{Conclusions}

The aggressiveness of the students in terms of gender is male and female middle category, which means that the level of aggressiveness of boys and girls is quite alarming and needs to do efforts to suppress acts of aggressiveness on the students.There are significant differences in which the average value of male students scores higher than female students. This means that male students have a tendency to behave physically aggressive than women, this is due to the role that is firmly attached to the boy dashing, brave and physically stronger than girls. A boy from childhood accustomed to playing the role of masculine violence.

\section{Acknowledgments}

In completing this study, researchers lot of help and guidance from the parties, to it as an expression of gratitude, researchers convey to the honorable:

Prof. Dr. Herman Nirvana, M. Pd., Kons. as Supervisor I and Mrs. Dr. Syahniar, M.Pd., Kons. as Advisor II who always took the time to provide guidance, direction, knowledge, and motivation so meaningful to the researcher for the perfection of the writing of this study.

Prof Dr. Word, MS, Kons. Dr. Alizamar, M.Pd., Kons. and Mrs. Prof. Dr. Solfema, M.Pd. as contributors also help researchers to weigh(judge)the research instrument that has provided direction, advice, and input in completing my thesis.

\section{References}

Aldrich, N. J., \& Tenenbaum, H.R. (2006)."Sadness, Anger, and Frustation: Gendered Patterns in Early Adolescents' and Their Parents' Emotion Talk". Sex Roles, 55(11-12): 775-785.

Alford, S. M. (2000). "A Qualitative Study of the College Social Adjusment of Back Students from Lower Socioeconomic Communities". Journal of Multicultural Counseling and Development. 28 (1): 2-15.

Aresa, V., Nirwana, H., \& Bentri, A. (2016).“Komunikasi Interpersonal Anak dan Orangtua Ditinjau dari Jenis Kelamin, Tingkat Pendidikan Orangtua dan Daerah Tempat Tinggal Serta Implikasinya Pada Bimbingan dan Konseling". Jurnal Konselor. 5 (3): 139-150.

Atkinson, R. T., Atkinson, R. C., \& Hilgard, E. R. (1983). Pengantar Psikologi. Jakarta: Erlangga.

Aulya, A., Ilyas, A., \& Ifdil, I. (2016). "Perbedaan Perilaku Agresif Siswa Laki-laki dan Siswa Perempuan".Jurnal EDUCATIO: Jurnal Pendidikan Indonesia, 2(1): 91-97.

Aziz, R., \& Mangestuti, R. (2006). “Pengaruh Kecerdasan Intelektual (IQ), Kecerdasan Emosional (EI) dan Kecerdasan Spiritual (SI) Terhadap Agresivitas Pada Mahasiswa UIN Malang". Jurnal Penelitian dan Pengembangan, 1(1): 1-10.

Berry, J. W., Poortinga, Y. H., Segall, M. H., \& Dasen, P. R. (2002). Cross-Cultural Psychology: Research and applications. New York: Cambridge University Press. 
Budiarti, D. (2015). “Disiplin Belajar Siswa Ditinjau dari Jenis Kelamin, Budaya, dan Penghasilan Orangtua serta Implikasinya bagi Bimbingan dan Konseling di SMA Se-Dharmasraya". Tesis tidak diterbitkan. Padang: Program Pascasarjana UNP.

Darmayanti, N. (2008). “Meta-Analisis: Gender dan Depresi Pada Remaja”. Jurnal Psikologi, 35(2): 164180.

Devi, S. (2016). “Orang Rejang dan Hukum Adatnya: Tafsiran atas kalpeak ukum adat ngen ca'o kutei jang kabupaten Rejang Lebong". Jurnal Antropologi: Isu-isu Sosial Budaya,18 (1): 39-50.

Diana, R. R., \&Retnowati, S. (2009). “Komunikasi Remaja-Orangtua dan Agresivitas Pelajar”.Jurnal Psikologi, 2(2): 141-150.

Fadila, R. (2013). “Hubungan Identitas Sosial dengan Perilaku Agresif pada Geng Motor".Psikologia: Jurnal Pemikiran dan Penelitian Psikologi, 8(2): 73-78.

Garaigordobil, M., Maganto, C., Pérez, J.I., \& Sansinenea, E. (2009). "Gender Differences in Socioemotional Factors During Adolescence and Effects of a Violence Prevention Program". Journal of Adolescent Health, 44(5): 468-477.

Geen, R., G \& Donnerstein, E. (1998). Human Aggression: Theories, research, and implications for social policy. San Diego: Academic Press.

Hasgimiati, Nirwana, H., \& Daharnis. (2017). "Perhatian Orangtua dan Motivasi Belajar Siswa yang Berlatar Belakang Melayu dan Jawa". Jurnal Bimbingan dan Konseling, 6(2): 130-142.

Herawati, A. A., Dharmayana, I., \& Sholihah, A. (2014)."Hubungan Antara Kecerdasan Emosional dengan Perilaku Agresif Siswa Kelas X TM (Teknik Mesin) SMKN 2 Kota Bengkulu".Doctoral Dissertation, Bengkulu: Universitas Bengkulu.

Ilahi, R., Syahniar \& Ibrahim, I. (2013).“Faktor Yang Mempengaruhi Pelanggaran Disiplin Siswa dan Implikasinya Terhadap Layanan Bimbingan dan Konseling".Jurnal Ilmiah Konseling, 2(2): 20-25.

Kartono, M. (2005). "Perbandingan Perilaku Agresif Antara Remaja yang Berasal dari Keluarga Bercerai dengan Keluarga Utuh".Jurnal Psikologi, 3(1): 1-18.

Koeswara, E. (1988). Agresi Manusia. Bandung: Eresco.

Krahe, B. (2005). Perilaku Agresif. Yogyakarta: Pustaka Pelajar.

Little, T. D., Henrich, C. C., Jones, S. M., \& Hawley, P. H. (2003). “Disentangling the 'whys' from the 'whats' of Aggressive Behavior". International Journal of Behavioral Development,27 (2): 122-133.

Maharani, O. P., \& Andayani, B. (2003).“Hubungan Antara Dukungan Sosial Ayah dengan Penyesuaian Sosial Pada Remaja Laki-laki".Jurnal Psikologi, 30(1): 23-35.

Mahmudah, D. (2012). "Representasi Perempuan Pada Teks Kekerasan Dalam Rumah Tangga". Jurnal Studi Komunikasi dan Media, 16(2): 137-150.

Masum, R., \& Khan, I. (2014). “Examining the Relationship between Emotional Intelligence and Aggression among Undergraduate Students of Karachi". Educational Research International, 3 (3): 36-41.

Mufrihah, A. (2014).“Implikasi Prinsip Bimbingan dan Konseling Terhadap Kompetensi Multikultural Konselor".Jurnal Pelopor Pendidikan, 7 (1): 73-85.

Novita, E. (2017).“Perbedaan Agresivitas Ditinjau dari Pola Asuh Orangtua”. Analitika, 4(2): 53-60.

Paiesa, R. (2017). Resiliensi pada Remaja Hamil di Luar Nikah. (Doctoral Dissertation, Universitas Mercu Buana Yogyakarta). 
Pratama, R., Syahniar \& Karneli, Y. (2016).“Perilaku Agresif Siswa Dari Keluarga Broken Home".Jurnal Konselor, 5(4): 238-246.

Prayitno. (2012). Jenis Layanan dan Kegiatan Pendukung Konseling. Padang: FIP Universitas Negeri Padang.

Rahman, A. K. M. R. (2009). "Cultural Differences in Aggression: a Case Study in Bangladesh". Journal Life Earth Sci, 3 (4):43-46.

Ramirez, J. M. (2015). “Justification of Aggression in Several Asian and European Countries with Different Religious and Cultural Background". International Journal of Behavior Development, 31 (1):9-15.

Santrock, J. W. (2003). Live-Span Development: Perkembangan Masa Hidup. Jakarta: Erlangga.

Santrock, J. W. (2007). Perkembangan Anak. Jakarta: Erlangga.

Sawalkar, V. S. (2015). "A Comparative Study on Aggression and Emotional Intelligence among College Students of Rural and Urban Area". The International Journal of Indian Psychology, 2 (2): 12-18.

Shaffer, D. R. (2005). Social and Personality Development. Belmont, California: Thomson Wadsworth.

Supriatna, M., \& Budiman, N. (2009). Bimbingan Karier di SMK.Dalam e-book.

Suwondo, B. (1979). Adat dan Upacara Perkawinan Daerah Bengkulu. Jakarta: Departemen Pendidikan dan Kebudayaan.

Syahadat, Y. M. (2013). “Pelatihan Regulasi Emosi untuk Menurunkan Perilaku Agresif pada Anak".Humanitas Jurnal Psikologi Indonesia, 10 (1): 19-36.

Winarlin, R., Lasan, B. B., \& Widodo, W. (2016).“Efektifitas Teknik Sosiodrama Melalui Bimbingan Kelompok Untuk Mengurangi Perilaku Agresif Verbal Siswa SMP".Jurnal Kajian Bimbingan dan Konseling, 1(2): 68-73. 